American Journal of Environmental Sciences 8 (3): 253-261, 2012

ISSN $1553-345 \mathrm{X}$

(C) 2012 Science Publications

\title{
Heavy Metal Contamination of Soils and Water Resources Kettara Abandoned Mine
}

\author{
${ }^{1,3}$ Mouhsine Esshaimi, ${ }^{1,3}$ Naaila Ouazzani, ${ }^{2}$ Marta Avila, \\ ${ }^{2}$ Gustavo Perez, ${ }^{2}$ Manuel Valiente and ${ }^{1,3}$ Laila Mandi \\ ${ }^{1}$ Laboratoire d'Hydrobiologie, Ecotoxicologie et Assainissement, \\ (LHEA, Unite associee au CNRST URAC 33), \\ Faculte des Sciences Semlalia, Universite Cadi Ayyad, \\ BP/2390, Marrakech 40 000, Maroc \\ ${ }^{2}$ Department of Chemistry, Faculty of Science, \\ University Autonomous of Barcelona, \\ Unit of Analytical Chemistry, Barcelona, Spain \\ ${ }^{3}$ National Centre for Studies and Research on Water and Energy, \\ University Cadi Ayyad, BP/511, 40000 Marrakech, Morocco
}

\begin{abstract}
Problem statement: Metal mining; together with mineral smelting and processing, have contaminated the environment surrounding mine areas throughout the world exceeding natural background concentration. Approach: These processes introduce metal contaminants into the environment through gaseous and particulate emissions, waste liquids and solid wastes. The principal objective of this study was to investigate soil and water contamination in the vicinity of the kettara abandoned mine located in the South of Morocco. Results: High total concentrations of heavy metals were found in both tailings and soil samples. Furthermore in the tailings the maximum concentrations of the mobile fraction of metals were 76,80 and $79 \mathrm{mg} \mathrm{kg}^{-1}$ of $\mathrm{Cu}, \mathrm{Pb}$ and $\mathrm{Zn}$, respectively, for the soil samples the maximum concentrations values were 68,52 and $26 \mathrm{mg} \mathrm{kg}^{-1}$ of $\mathrm{Cu}, \mathrm{Pb}$ and $\mathrm{Zn}$, respectively. As a result of dispersion of the metals downstream and downslope, soils contained higher metal concentrations than those from nearby control sites $(\mathrm{P}<0.05)$. This may be due to surface runoff and strong wind action which caused the movement of mine waste material. The chemical properties of tailings were characterized by very low $\mathrm{pH}$ and high levels of EC. Furthermore, in the wet season the water from kettara mine contained elevated levels of $\mathrm{Cu}, \mathrm{Pb}, \mathrm{Zn}$ and $\mathrm{SO}_{4}{ }^{2}$. Conclusion/Recommendations: According to this study, the agricultural activity in the vicinity of the kettara mine requires careful consideration. Recultivation of the tailings and the remediation of surface water and soil are recommended.
\end{abstract}

Key words: Water contamination, tailings, soil, heavy metals, mobility

\section{INTRODUCTION}

Mining is one of the most important sources of heavy metals in the environment. Mining and milling operation together with grinding, concentrating ores and disposal of tailings, along with mine and mill waste water, provides obvious sources of contamination. Heavy metal contamination has been one of the serious problems in the vicinity of abandoned mine sites. These heavy metals have a potential to contaminate soil and water. They can be dispersed and accumulated in plants and animals and taken in by human beings as a consumer. Human health risk assessment has been used to determine if exposure to a chemical, at any dose, could cause an increase in the incidence of adverse effects to human health (Fuge et al., 1989) Mining and milling/beneficiation processes (crushing, grinding, washing,) generate four major categories of waste, i.e. (i) Mine waste (low-grade ore, overburden and barren rocks), (ii) Tailings, (iii) Dump heap leach and (iv)

Corresponding Author: Laila Mandi, National Centre for Studies and Research on Water and Energy, University Cadi Ayyad, BP/511, 40000 Marrakech, Morocco Tel: +212 524457433 / 23 Fax : +212 524457815 
Acid mine water. These wastes are disposed in surrounding land and water in more or less environmentally acceptable manner.

Therefore, large areas of agricultural land can be contaminated. Morocco, for example, has a long history of metalliferous mining and the most extensive activities occurred during the early twentieth century. As a result, over 1000 metalliferous mines were distributed along mineralized zones; most of the mines were abandoned mainly due to economic reasons. Upon closure of the mines, mine waste materials, including tailings with elevated levels of toxic elements including As, $\mathrm{Cd}, \mathrm{Cu}, \mathrm{Pb}$ and $\mathrm{Zn}$, were left without full environmental treatment. Thus, soils, plants, waters and sediments in the vicinity of the mines have been contaminated by potentially toxic elements from tailings by clastic movement through wind and water. The principal objective of this study was to investigate soil and water contamination in the vicinity of the abandoned kettara mine located in the South of Morocco.

\section{MATERIALS AND METHODS}

Description of the area: The studied mine are located $30 \mathrm{~km}$ northwest of Marrakech in the core of the central Jebilet Mountains (Southern Morocco) Fig. 1 Hakkou et al., 2008). The Kettara mine produced more than 5.2 Million tons (Mt) of pyrrhotite from 1964-1981 and was closed in 1982 (Hakkou et al., 2008). During the exploitation, more than $3 \mathrm{Mt}$ of mine wastes were stockpiled over an area of 16ha without concern for environmental issues. The ore contains minerals such as pyrrhotite, sphalerite, galena, chalcopyrite, pyrite, arsenopyrite and glaucodot. The mine was exploited for $\mathrm{Cu}, \mathrm{Fe}$ and $\mathrm{S}$. The large quantities of waste materials, including tailings, have been left untreated. Thus; these materials have been dispersed downslope both by surface erosion and wind action and by effluent draining the wastes into lower lying land used for growth of paddy rice and household garden crops.

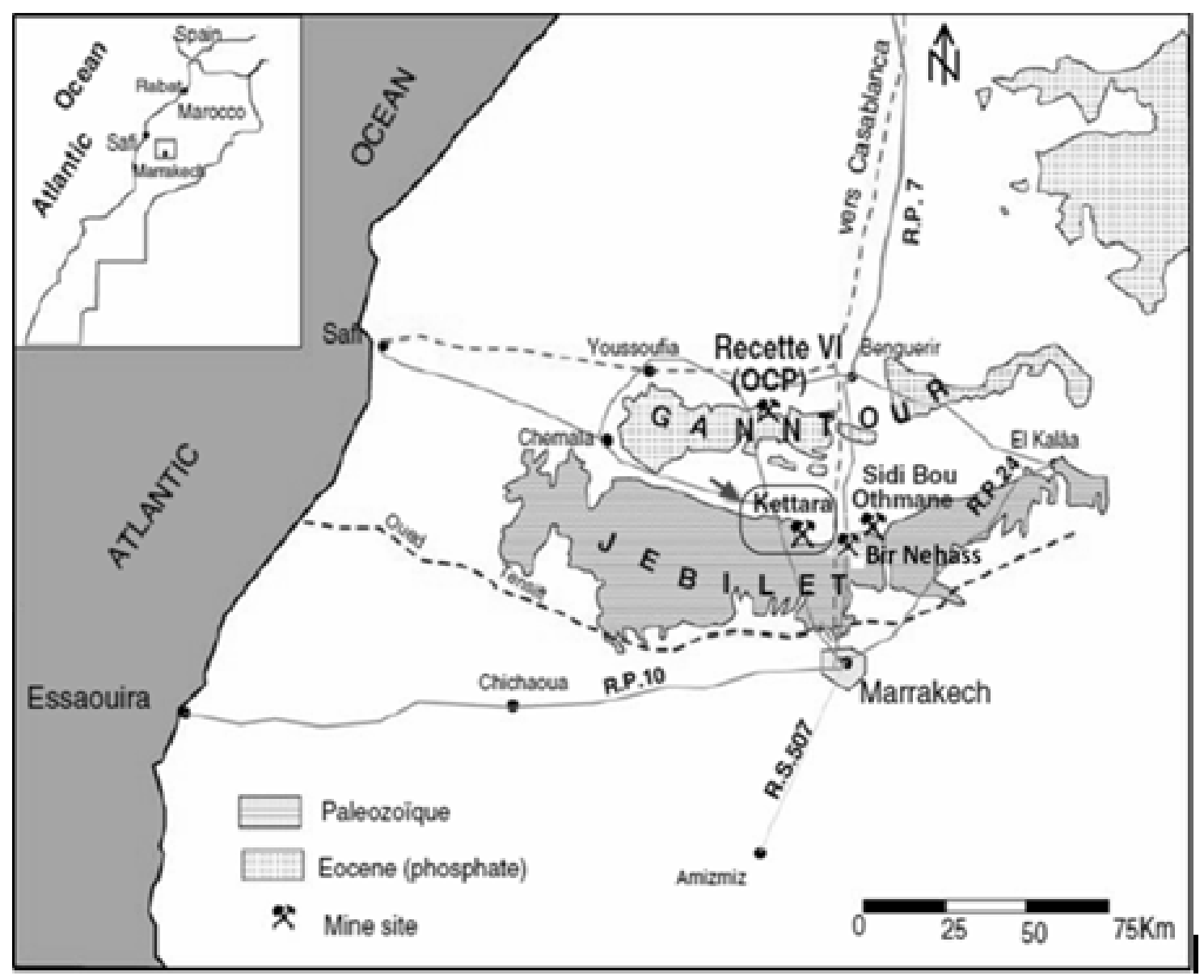

Fig. 1: Location of Kettara mine 
Am. J. Environ. Sci., 8 (3): 253-261, 2012

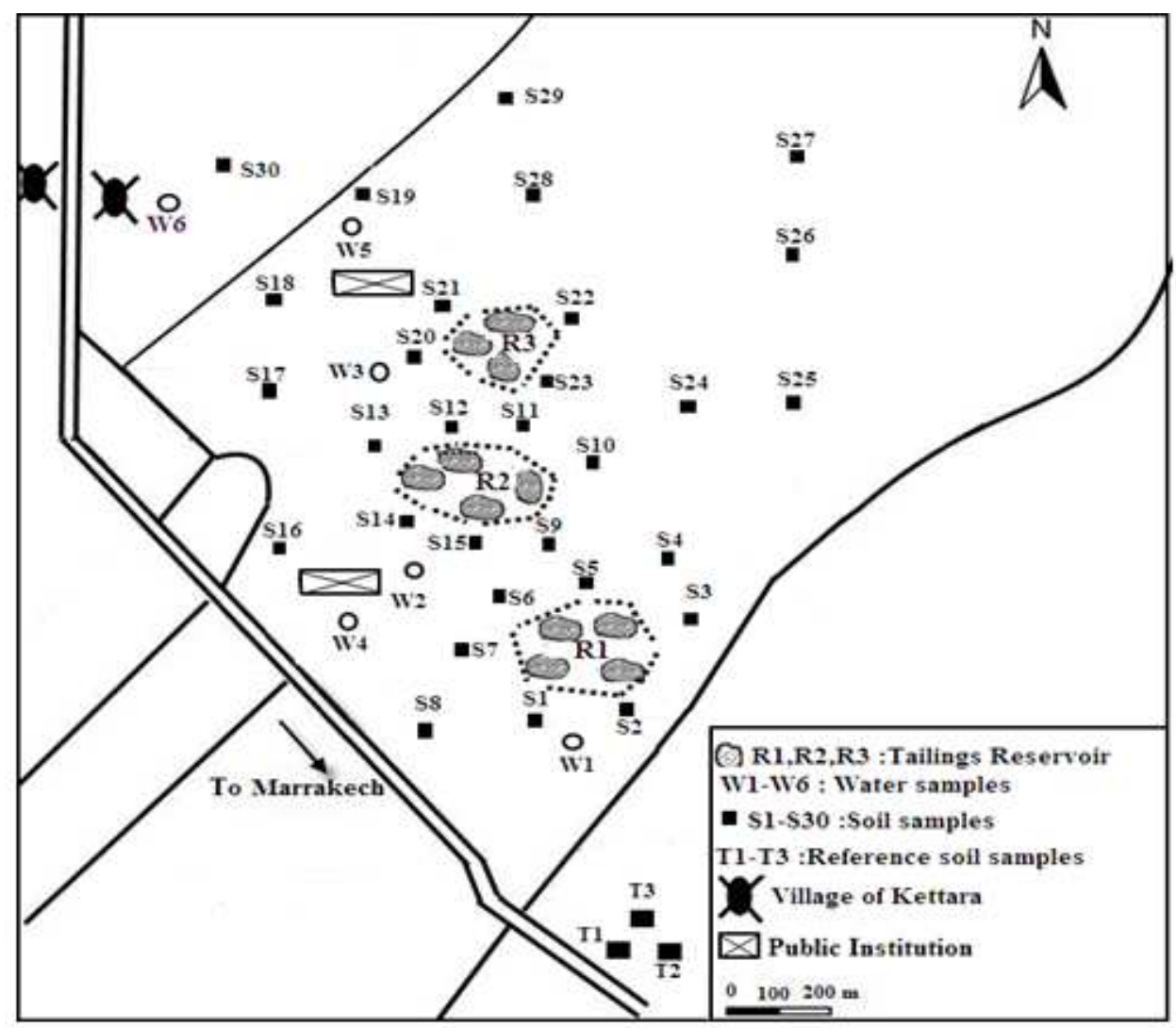

Fig. 2: Localization of the soil, the tailings and the water samples in and around the mine of kettara

Soils and tailings analysis: The samples of soil were taken from the upper $20 \mathrm{~cm}$ after removing the first layer of surface soil $2 \mathrm{~cm}$ within an area of $100 \mathrm{~cm}^{2}$ per sample. Additionally 3 representative background samples, namely T1-T3, were collected $1 \mathrm{~km}$ far away from the mining site Fig. 2. Each soil sample comprised a composite of 9 subsamples. 4 Tailing samples were also collected as undisturbed core, by using a specially designed cylindrical stainless steel corer. Soon after collection, the soil and tailing samples were carefully transferred to clean and dry self-sealing polyethylene bags for transport to laboratory. After being air-dried in paper lined propylene trays at room temperature and disaggregated with a wooden roller, all samples were sieved through 2 $\mathrm{mm}$ sieve. The tailing samples were thoroughly mixed and homogenized by coning and quartering, finally the soil and tailing samples were stored in tightly sealed polyethylene bags until further analysis.

The Physicochemical significant parameters of the soil and the Tailing samples such as $\mathrm{pH}$ values, Electrical Conductivity values (EC), Organic Matter (OM) and carbonate content were determined following the standard analytical methods (Aubert, 1978). Total heavy metal concentration in soil and tailing samples was determined after digestion of the samples with microwave assistance. $0.5 \mathrm{~g}$ dry sample (100 mesh) was weighted in a PTFE digestion vessel and $3 \mathrm{~mL} \mathrm{HNO} 3$ (70\%), $6 \mathrm{~mL} \mathrm{HCL} \mathrm{(37 \% )} \mathrm{and} 3 \mathrm{~mL} \mathrm{HF} \mathrm{(48 \% )} \mathrm{were}$ added. The digestion vessel was placed in the chamber of the microwave system (CEM MARS 5, Matthews, USA). After digestion, the sample solution was allowed to aircool and then diluted with deionized water to $50 \mathrm{~mL}$.

Mobility assays were performed by applying the established methodology (Perez et al., 2008) consisting on sample extraction with $\mathrm{HCl} 0,5 \mathrm{M}$ at 1:5 ratio during $1 \mathrm{~h}$ under magnetic stirring. After each extraction, the suspension was centrifuged and the supernatant was separated by filtering with $0.22 \mu \mathrm{m}$ filter (Millex GS, Millipore and Ireland). The concentrations of $\mathrm{Zn}, \mathrm{Cu}$ and $\mathrm{Pb}$ after total acid digestion and the resultant solutions of Mobility assays were determined by an Inductively Coupled Plasma Mass Spectrometer (Thermo Scientific XSERIES 2 ICP-MS). The isotopes ${ }^{65} \mathrm{Cu},{ }^{66} \mathrm{Zn},{ }^{111} \mathrm{Cd}$ and the sum of ${ }^{206} \mathrm{~Pb}+{ }^{207} \mathrm{~Pb}+{ }^{208} \mathrm{~Pb}$ were selected for the Determination 
of the elements of interest. ${ }^{72} \mathrm{Ge},{ }^{115} \mathrm{In}$ and ${ }^{209} \mathrm{Bi}$ (each $100 \mu \mathrm{GL}^{-1}$ ) were added to both the calibrated and sample solutions as internal standards to monitor and compensate for possible instrumental drift and matrix effects. Each experiment was conducted in triplicate and the results reported were the average values.

Waters analysis: Water samples were taken in and around the mine both in (dry and wet season) Fig. 2. The samples were filtered through $0.45 \mathrm{~mm}$ Millipre membrane filter .The $\mathrm{pH}$; Total Dissolved Solid (TDS), Electric Conductivity (EC) and temperature of the samples were measured using a portable pH-TDS-EC meter. After acidification with concentrated nitric acid, the samples were stored in a cool box before chemical analysis. For anion determination, the filtered waters were directly stored in a cool box without acidification. $\mathrm{Cu}, \mathrm{Pb}$ and $\mathrm{Zn}$ concentrations in acidified waters were determined by ICP-MS and the concentrations of $\mathrm{HCO}^{-}, \mathrm{NO}^{-}$and $\mathrm{SO}^{2-}$ in non-acidified waters were measured by Ion Chromatography (IC).

\section{RESULTS AND DISCUSSION}

Physical-Chemical properties of the soil and the Tailings samples: The results obtained for $\mathrm{pH}$, Electrical Conductivity (EC), Carbonate Content $(\mathrm{CaCo} 3)$, organic matter and total metal concentration for the soil and Tailings Samples are summarized in Table 1.

The results obtained revealed that, in general, all samples of tailings have a very acidic $\mathrm{pH}$ ranged from 1.9-2.8 this low $\mathrm{pH}$ may be due to the weathering of sulfide minerals (pyrite $(\mathrm{FeS} 2)$ and pyrrhotite $(\mathrm{FeS})$ which join other metal sulfides: chalcopyrite $(\mathrm{CuFeS} 2)$, glaucodot), galena and sphalerite have been observed but in very small proportions; a high electrical conductivity from 3000-3700 which means a high salt content, Organic matter content was mainly lower than $0.7 \%$ and a low concentration of carbonates (lower than $0.8 \%$,) indicating that the nature of these tailings is not calcareous Table 1.

Table 1: Summary of $\mathrm{pH}$, electrical conductivity $(\mathrm{EC})$, carbonate content $(\mathrm{CaCO} 3)$, organic matter $(\mathrm{OM})$ and total concentrations of $\mathrm{Cu}$, $\mathrm{Zn}$ and $\mathrm{Pb}$ for the soil and the Tailing samples taken at Kettara abandoned mine

\begin{tabular}{|c|c|c|c|c|c|c|c|}
\hline Type & $\mathrm{pH}$ & $\begin{array}{l}\text { EC } \\
(\mu \mathrm{S} / \mathrm{cm})\end{array}$ & $\begin{array}{l}\mathrm{CaCO} 3 \\
(\%)\end{array}$ & $\mathrm{OM}(\%)$ & $\begin{array}{l}\mathrm{Cu} \\
(\mathrm{Mg} / \mathrm{kg})\end{array}$ & $\begin{array}{l}\mathrm{Zn} \\
(\mathrm{Mg} / \mathrm{kg})\end{array}$ & $\begin{array}{l}\mathrm{Pb} \\
(\mathrm{Mg} / \mathrm{kg})\end{array}$ \\
\hline Tailing 1 $(\mathrm{n}=4)$ & 1.90 & 3700 & 0.41 & 0.60 & 1518.00 & 610 & 530 \\
\hline Tailing 2(n=4) & 2.10 & 3400 & 0.67 & 0.64 & 1248.00 & 510 & 400 \\
\hline Tailing $3(n=4)$ & 2.80 & 3000 & 0.77 & 0.68 & 780.00 & 230 & 100 \\
\hline S 1 & 3.90 & 1100 & 5.00 & 2.00 & 355.00 & 168 & 130 \\
\hline S2 & 3.70 & 1500 & 2.50 & 2.40 & 567.00 & 125 & 146 \\
\hline S3 & 3.40 & 1500 & 3.00 & 1.10 & 643.00 & 328 & 313 \\
\hline S4 & 4.70 & 970 & 4.50 & 2.10 & 281.00 & 51 & 120 \\
\hline S5 & 3.00 & 1500 & 4.00 & 1.75 & 772.00 & 145 & 310 \\
\hline S6 & 3.10 & 700 & 3.00 & 2.20 & 528.00 & 103 & 130 \\
\hline S7 & 5.10 & 1600 & 3.00 & 2.00 & 405.00 & 45 & 138 \\
\hline S8 & 7.70 & 100 & 2.00 & 2.40 & 98.00 & 26 & 81 \\
\hline S9 & 2.30 & 2300 & 2.00 & 2.00 & 814.00 & 406 & 349 \\
\hline $\mathrm{S} 10$ & 4.27 & 2100 & 2.10 & 2.30 & 487.00 & 171 & 134 \\
\hline S11 & 3.97 & 850 & 2.00 & 2.50 & 396.00 & 49 & 105 \\
\hline S12 & 4.02 & 670 & 4.00 & 2.60 & 424.00 & 60 & 106 \\
\hline S13 & 3.60 & 2100 & 3.30 & 2.90 & 987.00 & 47 & 133 \\
\hline S14 & 2.90 & 2350 & 5.00 & 1.40 & 1362.00 & 307 & 343 \\
\hline S15 & 2.85 & 2370 & 4.10 & 0.60 & 1347.00 & 101 & 101 \\
\hline S16 & 7.70 & 150 & 5.00 & 1.10 & 98.00 & 129 & 138 \\
\hline S17 & 7.60 & 180 & 3.00 & 1.40 & 61.00 & 28 & 87 \\
\hline S18 & 7.40 & 470 & 3.20 & 1.70 & 70.00 & 21 & 100 \\
\hline S19 & 7.90 & 120 & 4.00 & 1.05 & 65.00 & 38 & 90 \\
\hline S20 & 6.70 & 970 & 2.00 & 1.69 & 281.00 & 51 & 120 \\
\hline S21 & 6.20 & 1700 & 4.70 & 1.28 & 162.00 & 38 & 100 \\
\hline S22 & 7.34 & 520 & 2.30 & 2.00 & 242.00 & 44 & 121 \\
\hline S23 & 7.14 & 910 & 1.10 & 2.30 & 162.00 & 55 & 265 \\
\hline S24 & 7.70 & 180 & 3.50 & 2.50 & 53.00 & 25 & 82 \\
\hline S25 & 7.70 & 100 & 5.00 & 2.10 & 33.00 & 22 & 85 \\
\hline S26 & 7.60 & 100 & 5.30 & 2.30 & 38.00 & 28 & 77 \\
\hline S27 & 7.90 & 100 & 4.00 & 2.13 & 32.00 & 32 & 91 \\
\hline S28 & 7.30 & 70 & 3.00 & 2.53 & 27.00 & 27 & 77 \\
\hline S29 & 8.00 & 120 & 2.00 & 2.18 & 27.00 & 32 & 80 \\
\hline S30 & 7.30 & 70 & 2.00 & 2.02 & 27.00 & 43 & 61 \\
\hline Reference soil $(\mathrm{n}=3)$ & 8.12 & 60 & 3.10 & 2.84 & 29.00 & 13 & 55 \\
\hline
\end{tabular}


In general, the 30 soil samples featured widely different soil properties. The Organic matter content was mainly lower than $3 \%$ and ranged from 0.60 to $2.90 \%$. The presence of a vegetation cover in some parts of the mining area, could explain the high values of OM content in some samples of soil.

The $\mathrm{pH}$ values showed a very broad interval, from alkaline soils to soils close to strong acidity: points located near the both tailing reservoirs R1 and R2 present a very acidic $\mathrm{pH}(2.30-5.10)$ compared to the reference samples with basic $\mathrm{pH}(\mathrm{pH}=8.12)$, the others sampling points have a basic $\mathrm{pH}$ very close to the reference sample .

The acidic $\mathrm{pH}$ is related to the phenomenon of oxidation of metal sulphides and iron sulphides such as pyrite and pyrrhotite in the tailings, Metal sulfides, especially Pyrites, can be oxidized easily under natural weathering conditions, resulting in large quantities of AMD generated and transferred into the surrounding environment through atmospheric dispersion and through the flow of water and release of metals from the ore and tailings because of the low acidity and high salinity of percolating solutions. This was one of the most important sources of heavy metals in the environment surrounding the mine.

The study area Promoted by a topography which causes a flow from north to south of the mine, the alkaline $\mathrm{pH}$ of soils in northern part (Tailing 3) of the mine can be explained by the intervention of topographical factors, because the Tailings reservoir is located at a higher level compared with samples of soils, which meant that theses soils does not undergo the same changes on the $\mathrm{pH}$. The majority of samples taken around the tailing 1 and tailing 2 (tailing reservoir R1 and R2) present a high electric conductivity in comparison to the reference samples $\left(60 \mu \mathrm{s} \mathrm{cm}^{-1}\right)$. The electric conductivity in the nearest sites of R1 and R2 is ranged between $670-2370 \mu \mathrm{s} \mathrm{cm}^{-1}$ Table 1 . For the northern part (around the tailing reservoir R3) the electric conductivity is ranged between $520-1700 \mu \mathrm{s}$ $\mathrm{cm}^{-1}$. It is observed to have a decreasing salinity gradient from the mining site to the far away points (S8, S16, S17, S19, S24, S25, S26, S27, S28, S29 and S30). The carbonate content mean Range is between 0.60$2.9 \%$, the majority of the samples have carbonate content similar to those found in reference samples $(2.80 \%)$.

Total metal concentrations were classified based on the background levels for sandy soils (Kabata-Pendias and Pendias, 2001) and the upper values established by European Directive 86/278/EEC (86/278/EEC, 1986) for the addition of sludge as amendment to agricultural soils, the maximum allowable concentrations of heavy metals
$\mathrm{Cu}, \mathrm{Zn}$ and for agricultural soils is 140,300 and300 mg. $\mathrm{kg}^{-1}$ respectively. The Tailings contained mostly $\mathrm{Cu}$, $\mathrm{Zn}$ and $\mathrm{Pb}$ Table 1, the mean concentrations of $\mathrm{Cu}, \mathrm{Zn}$ and $\mathrm{Pb}$ in tailing $1(\mathrm{n}=4)$ were 1518,610 and 530 mg.kg- ${ }^{-1}$, in tailings $2(\mathrm{n}=4) 1248,510$ and $400 \mathrm{mg} \cdot \mathrm{kg}^{-1}$ and in tailings $3(\mathrm{n}=4) 780,330$ and $100 \mathrm{mg} \cdot \mathrm{kg}^{-1}$ respectively. The metal concentrations in the tailings exceeded the European standards (Usero et al., 2000; Hakkou et al., 2006) for $\mathrm{Cu}, \mathrm{Zn}$ and $\mathrm{Pb}$ in the tailing 1 , in the tailing 2 and for $\mathrm{Cu}, \mathrm{Zn}$ in the tailing 3 .

According to the European standards (KabataPendias and Pendias, 2001; 86/278/EEC, 1986) the majority of the soil samples located at the far away points of each reservoir of tailings (R, R2 and R3) showing values considered as background or tolerable levels for $\mathrm{Cu}, \mathrm{Zn}$ and $\mathrm{Pb}$. The soil samples taken around the area covered by mine tailing1 and tailings 2 (S1, S2, S3, S5, S6, S7, S9, S10, S11, S13, S14 and S15) showed the highest values for all the metals, the maximum concentrations of heavy metals in soils around the tailing 2 were 1347, 406 and $349 \mathrm{mg} \mathrm{kg}^{-1}$ of $\mathrm{Cu}, \mathrm{Zn}$ and $\mathrm{Pb}$, respectively, around the tailing 1 the maximum values of heavy metals were 772,328 and $310 \mathrm{mg} \mathrm{kg}^{-1}$ of $\mathrm{Cu}, \mathrm{Zn}$ and $\mathrm{Pb}$, respectively Table 1 .

According to the European standards (KabataPendias and Pendias, 2001; 86/278/EEC, 1986) the majority of the soil samples located around the tailing 1 and tailing 2 were classified into much polluted levels and exceed the maximum allowable concentrations of heavy metals $\mathrm{Cu}, \mathrm{Zn}$ and $\mathrm{Pb}$ for agricultural soils.

Contamination Factor $(\mathbf{C F})$ : The $\mathrm{CF}$ is the ratio obtained by dividing the concentration of each metal in the soil by the baseline or background value (Eq. 1) (concentration in unpolluted soil) Table 2:

$\mathrm{CF}=\left(\mathrm{C}_{\text {heary metal }} / \mathrm{C}_{\text {background }}\right)$

The contamination levels may be classified based on their intensities on a scale ranging from 1-6 $(0=$ none, $1=$ none to medium, $2=$ moderate, $3=$ moderately to strong, $4=$ strongly polluted, $5=$ strong to very strong, $6=$ very strong) (Muller, 1969).

Pollution Load Index (PLI): For the entire sampling site, PLI has been determined by the calculation of the product of the $\mathrm{CF}$ (Eq. 2) (Usero et al., 2000) Table 2:

$\mathrm{PLI}=\left(\mathrm{CF}_{1} \times \mathrm{CF}_{2} \times \mathrm{CF}_{3} \times \cdots \times \mathrm{CF}_{\mathrm{n}}\right)^{1 / \mathrm{n}}$

where, $\mathrm{n}$ is the number of metals ( $\mathrm{n}=3$ in this study) index provides a simple, comparative means for assessing the level of heavy metal pollution. 
Am. J. Environ. Sci., 8 (3): 253-261, 2012

The Pollution Load Index (PLI) calculated from CF shows that the soils are moderately to heavily contaminate by investigated heavy metals Table 2 .

The sampling Sites located around the tailings (S14, S9, S3, S5, S15, S1 and S2), shows the highest PLI more than 7 within the sampling Sites S4,S6, S7, $\mathrm{S} 16, \mathrm{~S} 12, \mathrm{~S} 20$ and S23) and the rest of the area is low to moderately polluted. Statistical analysis of the total metal concentrations showed a high significant correlation between metals in all the sampling points $(\mathrm{P}<0.05)$. This fact suggests the common origin of all the metals analyzed and, therefore, the mining activity can be pointed out as the source for the metal pollution of the studied area The agricultural soils that are irrigated by mine drainage water contain very high levels of potentially toxic trace elements, although the total contents vary considerably depending on the location of the samples Table 1.

Two reasons may be suggested to explain the scattering of the metals from the mine area. Firstly, the physicochemical properties of the Kettara mine tailings Table 1, i.e., high heavy metal concentrations, low $\mathrm{pH}$, low carbonates content, nature of the deposit: mine tailings contain sulfides which react with oxygen, generating a stream of acid water that also contains dissolved heavy metals and other minerals that can be transported to the mine surroundings by means of acidic drainage, aided by a topography which causes a flow from north to South of the mine. Secondly, wind transport of dust may be another important factor influencing the spreading of pollution. Previous study in the same site (Hakkou et al., 2006) showed that runoff have an acidic $\mathrm{pH}(<3)$. This acidity favors the attack of the mineral content in discharges and release of contaminants in solution. According to these authors, this runoff is highly sulfated and has a very high salinity, resulting in a very high conductivity (Hakkou et al., 2006)

Production of Acid Mine Drainage (AMD) in addition to decreasing $\mathrm{pH}$, inevitably the leaching of various metals and high concentrations of sulfates (Hakkou et al., 2006). In the reference area, however, the average concentrations of the metals are close to the world average of 30,35 and $90 \mathrm{mg}$ $\mathrm{kg}^{-1}$ of $\mathrm{Cu}, \mathrm{Pb}$ and $\mathrm{Zn}$, respectively, reported by (Bowen, 1979). There is a statistically significant difference between metal concentrations in the contaminated and reference soils $(\mathrm{P}<0.05)$.

Mobility of $\mathbf{C u}, \mathbf{P b}$ and $\mathbf{Z n}$ in soil: Once detected the most polluted samples of soil, a real evaluation of their potential risk can be obtained from the results of metals mobility, by using the single extraction procedure, the concentrations of heavy metals in soils extracted by the $\mathrm{HCl}$ 0, $5 \mathrm{M}$ solution are shown in Table 3.
Table 2: Calculation of the Contamination Factor (CF) and the Pollution Load Index (PLI) for the soil and the Tailing samples taken at Kettara abandoned mine

\begin{tabular}{|c|c|c|c|c|}
\hline & $\mathrm{Cu}$ & $\mathrm{Zn}$ & $\mathrm{Pb}$ & \\
\hline Type & $\mathrm{CF}$ & $\mathrm{CF}$ & $\mathrm{CF}$ & (PLI) \\
\hline Tailing 1(n=4) & 52.00 & 46.92 & 9.63 & 28.64 \\
\hline Tailing 2(n = 4) & 43.03 & 39.23 & 7.27 & 23.07 \\
\hline Tailing $3(n=4)$ & 26.90 & 17.69 & 1.81 & 9.51 \\
\hline $\mathrm{S} 1$ & 12.24 & 12.92 & 2.36 & 7.20 \\
\hline $\mathrm{S} 2$ & 19.55 & 9.62 & 2.65 & 7.93 \\
\hline S3 & 22.17 & 25.23 & 2.69 & 11.46 \\
\hline S4 & 9.69 & 3.92 & 2.18 & 4.36 \\
\hline S5 & 26.62 & 11.15 & 5.63 & 11.87 \\
\hline S6 & 18.21 & 7.92 & 2.36 & 6.98 \\
\hline S7 & 13.97 & 3.46 & 2.50 & 4.94 \\
\hline S8 & 3.38 & 2.00 & 1.47 & 2.15 \\
\hline S9 & 28.07 & 31.23 & 6.34 & 17.71 \\
\hline $\mathrm{S} 10$ & 16.79 & 13.15 & 2.43 & 8.13 \\
\hline S11 & 13.66 & 3.77 & 1.90 & 4.61 \\
\hline $\mathrm{S} 12$ & 14.62 & 4.62 & 1.92 & 5.06 \\
\hline S13 & 34.03 & 3.62 & 2.41 & 6.67 \\
\hline S14 & 46.97 & 23.62 & 6.24 & 19.05 \\
\hline $\mathrm{S} 15$ & 46.45 & 7.77 & 1.83 & 8.71 \\
\hline S16 & 3.38 & 9.92 & 2.50 & 4.38 \\
\hline S17 & 2.10 & 2.15 & 1.58 & 1.93 \\
\hline $\mathrm{S} 18$ & 2.41 & 1.62 & 1.81 & 1.92 \\
\hline S19 & 2.24 & 2.92 & 1.63 & 2.20 \\
\hline $\mathrm{S} 20$ & 9.69 & 3.92 & 2.18 & 4.36 \\
\hline S21 & 5.59 & 2.92 & 1.81 & 3.09 \\
\hline $\mathrm{S} 22$ & 8.34 & 3.38 & 2.20 & 3.96 \\
\hline $\mathrm{S} 23$ & 5.59 & 4.23 & 4.81 & 4.84 \\
\hline S24 & 1.83 & 1.92 & 1.49 & 1.74 \\
\hline S25 & 1.14 & 1.69 & 1.55 & 1.44 \\
\hline S26 & 1.31 & 2.15 & 1.40 & 1.58 \\
\hline S27 & 1.10 & 2.46 & 1.65 & 1.65 \\
\hline S28 & 0.93 & 2.08 & 1.40 & 1.39 \\
\hline S29 & 0.93 & 2.46 & 1.45 & 1.49 \\
\hline $\mathrm{S} 30$ & 0.93 & 3.31 & 1.11 & 1.51 \\
\hline
\end{tabular}

Table 3: The mobility of $\mathrm{Cu}, \mathrm{Pb}$ and $\mathrm{Zn}$ in the most contaminated samples of Kettara $\left(\mathrm{mg} \mathrm{kg}^{-1}\right)$

\begin{tabular}{|c|c|c|c|c|c|c|}
\hline \multirow[b]{2}{*}{ Type } & \multicolumn{2}{|l|}{$\mathrm{Cu}$} & \multicolumn{2}{|l|}{$\mathrm{Pb}$} & \multicolumn{2}{|l|}{$\mathrm{Zn}$} \\
\hline & Total & Mobile & Total & Mobile & Total & Mobile \\
\hline Tailing1 & 1518 & 76 & 610 & 49 & 530 & 80 \\
\hline Tailing 2 & 1248 & 62 & 510 & 41 & 400 & 60 \\
\hline Tailing3 & 780 & 39 & 230 & 18 & 100 & 15 \\
\hline S 1 & 355 & 18 & 168 & 13 & 130 & 20 \\
\hline $\mathrm{S} 2$ & 567 & 28 & 125 & 10 & 146 & 22 \\
\hline $\mathrm{S} 3$ & 643 & 32 & 328 & 26 & 313 & 47 \\
\hline S5 & 772 & 38 & 145 & 12 & 310 & 46 \\
\hline S6 & 528 & 26 & 103 & 8 & 130 & 19 \\
\hline S7 & 405 & 20 & 45 & 4 & 138 & 21 \\
\hline S9 & 814 & 41 & 406 & 32 & 349 & 52 \\
\hline S10 & 487 & 24 & 171 & 14 & 134 & 20 \\
\hline S11 & 396 & 19 & 49 & 4 & 105 & 16 \\
\hline S12 & 424 & 21 & 60 & 5 & 106 & 16 \\
\hline S13 & 987 & 49 & 47 & 4 & 133 & 20 \\
\hline S14 & 1362 & 68 & 307 & 25 & 343 & 52 \\
\hline $\mathrm{S} 15$ & 1347 & 67 & 101 & 8 & 101 & 15 \\
\hline S20 & 281 & 14 & 51 & 4 & 120 & 18 \\
\hline Reference soil & 29 & $\mathrm{Nd}$ & 15 & $\mathrm{Nd}$ & 55 & 4 \\
\hline
\end{tabular}

$\mathrm{ND}$, not detected (lower instrumental detection limit

The maximum concentrations of the metals were found in the tailings sites (R1-R3) Fig. 2 with up to 7649 and $80 \mathrm{mg} \mathrm{kg}^{-1}$ of $\mathrm{Cu}, \mathrm{Pb}$ and $\mathrm{Zn}$, respectively. For 
soil samples the maximum concentrations of mobile fraction were found in the soil around the tailings (R1R3) with were $68-32$ and $52 \mathrm{mg} \mathrm{kg}^{-1}$ of $\mathrm{Cu}, \mathrm{Pb}$ and $\mathrm{Zn}$, respectively, this Mobility assays indicates also that the mobile fraction present about $15 \%$ of $\mathrm{Zn}, 10 \%$ of $\mathrm{Pb}$ and $5 \%$ of $\mathrm{Cu}$ in the soil samples; this indicated that the mobility $\mathrm{Zn}$ and $\mathrm{Pb}$ was high than that of $\mathrm{Cu}$ and we know that the bioavailability and eco-toxicity of metals mainly depends on their speciation in soil.

However, were relatively low in a nearby control area with, the results indicate that there is a statistical difference between average metal concentrations in the contaminated and reference soils $(\mathrm{P}<0.05)$.

In general Heavy metals in soil are distributed in 4 fractions: the mobile fraction, the reducible fraction, the oxidizable fraction and the residual fraction, the mobile fraction and the reducible fraction are readily to be absorbed in plants or in water system causing pollution. So, these fractions should be identified as direct effect fraction. Because the all the soil samples analyzed for Mobility assays are acidic and located in AMD area, the soil has highly oxidizing property.

The oxidizable fraction in this oxidizing condition is easily mobilized and transformed into mobile fraction or reducible fraction, potential of that eco-toxicity should not be ignored. So, the oxidizable fraction can be identified as potential effect fraction.

The heavy metal bound to residual fraction is often considered "unreactive" and not affected by environment changes, is identified as stable fraction. Therefore, it could be inferred that the potential environmental impact of heavy metals in soils was related not only to their total concentrations and chemical forms, but also could increase with time depending of $\mathrm{pH}, \mathrm{EC}$ and the content of organic matter.

The chemical properties and concentrations of $\mathrm{Cu}, \mathrm{Pb}$ and $\mathrm{Zn}$ in water samples: The chemical properties and the concentrations of $\mathrm{Cu}, \mathrm{Pb}$ and $\mathrm{Zn}$ in water waters are shown in Table 4 . The $\mathrm{pH}$ values was found being lower in mine waters (W1-W3) located nearest the tailings (R1$\mathrm{R} 3$ ) the $\mathrm{pH}$ values were ranged from $2.60-5$ for waters taken in dry season and from 2.20-4.10 in wet season, the $\mathrm{pH}$ in waters samples (W4-W6), located to the far away points of the tailings was higher than 7.12.
The relatively low water $\mathrm{pH}$ of mine waters may be due to the dissolution and decomposition of sulfide minerals including pyrite in mine waste dumps tailings. Total Dissolved Solid (TDS) give information on the total cations and anions in waters. Because effluent draining the mine wastes contained elevated levels of those ions, the maximum TDS of water samples in the effluent was $980 \mathrm{~m} \mathrm{~L}^{-1}$ sampled in the dry season and $1185 \mathrm{~m} \mathrm{~L} \mathrm{~L}^{-1}$ sampled in the wet season, Electric Conductivity (EC) is positively correlated with TDS. The highest EC was found in effluent draining from the mine wastes with $2700 \mu \mathrm{S} \mathrm{cm}^{-1}$ sampled in dry season and $3280 \mu \mathrm{S} \mathrm{cm}^{-1}$ sampled in wet season. TDS, EC and concentrations of metals in waters decreased with distance from the tailings.

In general, metal concentrations in natural waters are very low due to their low solubility in the aquatic environment. According to (Bowen, 1979), fresh water contains 3.0, 3.0 and $15 \mathrm{~m} / \mathrm{L}$ of $\mathrm{Cu}, \mathrm{Pb}$ and $\mathrm{Zn}$, respectively. However, tens to hundreds of times these concentrations of the metals can be found in waters contaminated by various sources (Fergusson, 1990). The concentrations of $\mathrm{Cu}, \mathrm{Pb}$ and $\mathrm{Zn}$ in water samples are also shown in Table 3. High concentrations of heavy metals were found in mine waters taken in the wet season, with maximum contents of $1.90,4.15$ and $33.00 \mathrm{~m} \mathrm{~L}^{-1}$ of $\mathrm{Cu}, \mathrm{Pb}$ and $\mathrm{Zn}$, respectively. These concentrations may be derived from interaction of rain with tailings containing elevated levels of these metals. Heavy metals from acidic tailings with sulfide minerals can be extracted by large amounts of rain, especially in the wet season.

Thus, they can be continuously discharged downstream and decreased exponentially with distance from the mine.

The dispersion patterns of these metals varied depending upon their solubility and mobility in the aquatic environment. In general, $\mathrm{Zn}$ with higher mobility can be widely dispersed downstream and $\mathrm{Cu}$ and $\mathrm{Pb}$ with lower solubility can be dispersed only to the area adjacent to the tailings.

Table 4: The chemical properties and concentrations of $\mathrm{Cu}, \mathrm{Pb}$ and $\mathrm{Zn}$ in water samples

\begin{tabular}{|c|c|c|c|c|c|c|c|c|c|c|c|c|}
\hline \multirow[b]{2}{*}{ Sample ID } & \multicolumn{6}{|c|}{ Samples in dry season } & \multicolumn{6}{|c|}{ Samples in wet season } \\
\hline & $\mathrm{pH}$ & $\begin{array}{l}\text { TDS } \\
(\mathrm{mg} / \mathrm{l})\end{array}$ & $\begin{array}{l}\mathrm{EC} \\
(\mu \mathrm{S} / \mathrm{cm})\end{array}$ & $\mathrm{Cu}(\mathrm{mg} / \mathrm{l})$ & $\mathrm{Zn}(\mathrm{mg} / \mathrm{l})$ & $\mathrm{Pb}(\mathrm{mg} / \mathrm{l})$ & $\mathrm{pH}$ & $\begin{array}{l}\text { TDS } \\
(\mathrm{mg} / \mathrm{l})\end{array}$ & $\begin{array}{l}\mathrm{EC} \\
(\mu \mathrm{S} / \mathrm{cm})\end{array}$ & $\mathrm{Cu}(\mathrm{mg} / \mathrm{l})$ & $\mathrm{Zn}(\mathrm{mg} / \mathrm{l})$ & $\mathrm{Pb}(\mathrm{mg} / \mathrm{l})$ \\
\hline$\overline{\mathrm{W} 1}$ & 2.60 & 980.0 & 2700.0 & 0.70 & 18.8 & 0.30 & 2.20 & 1185.00 & 3280.0 & 1.90 & 33.00 & 4.15 \\
\hline W2 & 4.70 & 350.0 & 549.0 & 0.44 & 6.70 & 0.20 & 3.90 & 379.00 & 615.0 & 1.23 & 15.96 & 2.85 \\
\hline W3 & 5.00 & 288.0 & 479.0 & 0.28 & 4.71 & 0.12 & 4.10 & 295.00 & 513.0 & 0.93 & 12.85 & 0.50 \\
\hline W4 & 7.45 & 8.7 & 16.0 & 0.02 & ND & ND & 7.12 & 13.15 & 21.5 & 0.02 & ND & ND \\
\hline W5 & 7.76 & 9.0 & 16.7 & 0.02 & ND & ND & 7.50 & 22.18 & 19.0 & 0.02 & ND & ND \\
\hline W6 & 7.67 & 8.0 & 14.7 & 0.01 & ND & ND & 7.21 & 18.00 & 18.0 & 0.02 & ND & ND \\
\hline
\end{tabular}

$\mathrm{ND}$, not detected (lower instrumental detection limit 
Am. J. Environ. Sci., 8 (3): 253-261, 2012

Table 5: The concentrations of some anions in waters in and around the kettara mine $\left(\mathrm{mg}_{\mathrm{kg}}{ }^{-1}\right)$

\begin{tabular}{|c|c|c|c|c|c|c|}
\hline \multirow[b]{2}{*}{ Sample ID } & \multicolumn{3}{|c|}{ Samples in dry season } & \multicolumn{3}{|c|}{ Samples in wet season } \\
\hline & $\mathrm{HCO}^{-}$ & $\mathrm{NO}^{-}$ & $\mathrm{SO}^{2}{ }^{2}$ & $\mathrm{HCO}^{-}$ & $\mathrm{NO}^{-}$ & $\mathrm{SO}_{4}^{2}$ \\
\hline W1 & 0.00 & 9.40 & 1200 & 12.00 & 7.12 & 4200 \\
\hline W2 & 9.85 & 4.74 & 1100 & 3.90 & 3.12 & 2800 \\
\hline W3 & 21.03 & 3.58 & 1010 & 4.10 & 2.78 & 1589 \\
\hline W4 & 14.52 & ND & 325 & 7.12 & 1.50 & 680 \\
\hline W5 & 26.90 & ND & 311 & 7.30 & 1.00 & 512 \\
\hline W6 & 44.10 & 0.05 & 155 & 24.52 & 3.00 & 241 \\
\hline
\end{tabular}

Anion concentrations in waters samples: The concentrations of $\mathrm{HCO}^{-}, \mathrm{NO}^{-}$and $\mathrm{SO}^{2-}$ in water samples are shown in Table 5: All the samples contained less than $45 \mathrm{mg} 1$ of bicarbonates, High concentrations of $\mathrm{SO}^{2-}$, over $1000 \mathrm{mg} / \mathrm{L}$, were also found in the waters sampled in both the dry and wet seasons (waters around the tailings). These levels are likely to be due to the oxidation and dissolution of sulfide minerals in tailings. However, the concentrations of NO3 in all the water samples were relatively low.

\section{CONCLUSION}

The principal objective of this study was to investigate soil and water contamination in the vicinity of the abandoned kettara mine located in the South of Morocco. This investigation was based firstly on the determination of total concentration of several heavy metals $(\mathrm{Pb}, \mathrm{Zn}, \mathrm{Cu})$ in both soil and water (dry season and wet season) by ICP-MS, secondly on the determination Mobility of $\mathrm{Pb}, \mathrm{Zn}$ and $\mathrm{Cu}$ in the most polluted soil and tailings samples by using the single extraction procedure with solution of $\mathrm{HCl} 0,5 \mathrm{M}$ ), finally on the determination of some anions (HCO3-, NO3-, $\left.\mathrm{SO}_{4}{ }^{2}\right)$ in water taken in and around the mine both in dry season and wet season by Ion Chromatography (IC). In this study of an area around the abandoned kettara mine, soils and waters have been contaminated by past mining activity. High concentrations of heavy metals extracted by acid digestion were found in tailings with maximum values $\mathrm{Cu}$ (1500 mg.kg $\left.{ }^{-1}\right), \mathrm{Pb}$ (510 mg.kg ${ }^{-1}$ ) and $\mathrm{Zn} \mathrm{(650}$ $\left.\mathrm{mg} \cdot \mathrm{kg}^{-1}\right)$. A high total concentration of heavy metals was also found in soil samples with maximum values, $\mathrm{Cu}$ (1347 mg.kg $\left.{ }^{-1}\right), \mathrm{Pb}$ (349 mg.kg ${ }^{-1}$ ) and $\mathrm{Zn} \mathrm{(406}$ mg.kg $\left.{ }^{-1}\right)$.

Furthermore in the tailings the maximum concentrations of the mobile fraction of metals determined by extraction in $0.5 \mathrm{~N} \mathrm{HCl}$ were 76,80 and $79 \mathrm{mg} \cdot \mathrm{kg}^{-1}$ of $\mathrm{Cu}, \mathrm{Pb}$ and $\mathrm{Zn}$, respectively, for the soil samples the maximum concentrations values were 68 ,
52 and $26 \mathrm{mg} \cdot \mathrm{kg}^{-1}$ of $\mathrm{Cu}, \mathrm{Pb}$ and $\mathrm{Zn}$, respectively, this Mobility assays indicates also that the mobile fraction present about $15 \%$ of $\mathrm{Zn}, 10 \%$ of $\mathrm{Pb}$ and $5 \%$ of $\mathrm{Cu}$ in the soil samples; this indicated that the mobility $\mathrm{Zn}$ and $\mathrm{Pb}$ was high than that of $\mathrm{Cu}$.

Pollution Load Indices (PLIs) derived from contamination factors show that all sampling points around the tailings reservoir area exceed unity and may be considered as highly polluted sites. Lower values for $\mathrm{pH}$ and higher levels of TDS and EC are found in waters sampled immediately downstream of effluents passing through tailings. Furthermore, high levels of heavy metals are found in the water. Thus, it can be understood that the main source of heavy metals in waters is the tailings containing elevated levels of the metals. In addition, over $1000 \mathrm{mg} \mathrm{L}^{-1}$ of $\mathrm{SO}^{2-}$ is also found in the effluents, mainly due to leaching and oxidizing of sulfide minerals including pyrite, arsenopyrite, galena and sphalerite in tailings. Like dispersion patterns of soils, heavy metal concentrations in waters exponentially decreased with increasing distance from the tailings and they reach background levels at $1 \mathrm{~km}$ downstream. Tailing dumps have mainly a local impact and it is most likely that the activity of wind does not contribute significantly to contamination of surroundings. The higher heavy metal content in close proximity to the tailings is likely due to leaching and surface runoff.

The latter is a consequence of an inadequate deposition of the waste material .Shows the fate and impact of the tailing dump. The leachate of the tailing dump may contaminate the soil and groundwater. Surface runoff increases the heavy metal content of top soil, surface water and indirectly, the tissues of plants.

All these elements are receiving environment surrounding the mine abandoned Kettara, an area with a high risk of metal pollution that can affect water, soil, fauna, flora and undoubtedly human health of the area nearest and around the mine of kettara. Hence the importance of providing substantial efforts to develop methods of restoration and remediation cost-effective.

\section{ACKNOWLEDGEMENT}

This study was supported by: -PC2E (Pole de competences Eau et Environnement), -Project of cooperation Morocco-Spanish No. A/011433/07«Estudio de la Movilidad de metales pesados en suelos contaminados »-European project, FP7 SOWAEUMED (Network in Solid Waste and Water Treatment between Europe and Mediterranean Countries, Contract $\mathrm{N}^{\circ} 245843$ ). 


\section{REFERENCES}

86/278/EEC, 1986. Council of the European Communities, Directive on the protection of the environment and in particular of the soil, when sewage sludge is used in agriculture. Off. J. Eur. Commun., L181: 6-12.

Aubert, G., 1978. Methodes d'analyses des sols. G.R.D.P., Marseille.

Bowen, H.J.M., 1979. Environmental Chemistry of the Elements. 1st Edn., Academic Press, London, ISBN-10: 0121204502, pp: 333.

Fergusson, J.E., 1990. The Heavy Elements: Chemistry, Environmental Impact and Health Effects. 1st Edn., Pergamon Press, Oxford, New York, ISBN-10: 0080348602, pp: 614.

Fuge, R., C.F. Paveley and M.T. Holdham, 1989. Heavy metal contamination in the Tanat Valley, North Wales. Environ. Geochem. Health, 11: 127135. DOI: $10.1007 / \mathrm{BF} 01758662$

Hakkou, R., M. Benzaazoua and B. Bussiere, 2008. Acid mine drainage at the abandoned kettara mine (Morocco): 1. Environmental characterization. Mine Water Environ., 27: 145-159. DOI: 10.1007/s10230-008-0036-6
Hakkou, R., M. Benzaazoua and B. Bussiere, 2006. Evaluation of Qualite Des Eaux De Dans La Mine Ruissellement Abandonnée of Kettara (Maroc), GIRE3D. 1st Edn., Marrakech (Maroc), pp: 5.

Kabata-Pendias, A and H. Pendias, 2001. Trace Elements in Soils and Plants. 3rd Edn., CRC Press, Boca Raton, ISBN-10: 0849315751, pp: 413.

Muller, G., 1969. Index of geoaccumulation in sediments of the Rhine River. Geojournal, 2: 108118.

Perez, G., M. Lopez-Mesas and M. Valiente, 2008. Assessment of heavy metals remobilization by fractionation: Comparison of leaching tests applied to roadside sediments. Environ. Sci. Technol., 42: 2309-2315. PMID: 18504958

Usero, J., A. Garcia and J. Fraidias, 2000. Andalicia Board, Environmental Counseling. 1st Edn., Seville, Editorial, pp: 164. 